\title{
INOVASI PRODUK CITRUS INFUSED HONEY TEA DENGAN PENAMBAHAN ROSELA (HIBISCUS SABDARIFFA LINN.) (KAJIAN KONSENTRASI ROSELA DAN LAMA INFUSING)
}

\author{
Inovation of Citrus Infused Honey Tea with Added Roselle (Hibiscus sabdariffa Linn.) \\ (Study of Concentration of Roselle and Period of Infusing) \\ Anastasia Intan Kurniasari, Erni Sofia Murtini* \\ Jurusan Teknologi Hasil Pertanian - Fakultas Teknologi Pertanian - Universitas Brawijaya \\ Jl. Veteran, Malang 65145 \\ *Penulis Korespondensi: email: ernisofia@yahoo.com
}

\begin{abstract}
ABSTRAK
Citrus infused honey tea di Indonesia merupakan produk inovasi dari pengolahan madu yang diharapkan dapat memberikan manfaat yang lebih besar dibandingkan produk turunan madu lainnya. Rosela ditambahkan untuk meningkatkan kualitas kenampakan dan memberikan warna merah alami pada produk. Tujuan penelitian ini untuk mengetahui pengaruh serta kombinasi konsentrasi rosela dan lama infusing pada kualitas citrus infused honey tea serta mengetahui karakteristik fisikokimia perlakuan terbaik citrus infused honey tea. Penelitian ini menggunakan Rancangan Acak Lengkap (RAL) faktorial dengan 2 faktor, yaitu konsentrasi rosela (10\%, 15\%, dan 20\%), serta lama infusing (1 hari dan 7 hari). Perlakuan terbaik ditentukan dengan metode Zeleny. Hasil penelitian menunjukkan bahwa konsentrasi rosela, lama infusing, dan interaksinya berpengaruh nyata terhadap parameter organoleptik. Perlakuan terbaik diperoleh pada konsentrasi rosela 15\% dan lama infusing 7 hari. Karakteristik perlakuan terbaik pekatan citrus infused honey tea meliputi warna ( $\mathrm{L}^{*} 28.3$; $\left.\mathrm{a}+17.6 ; \mathrm{b}+3.9\right)$, TPT $66.27 \%$, viskositas $11.210 \mathrm{cps}$, kadar air $30.37 \%$, vitamin C $35.66 \mathrm{mg} / 100 \mathrm{~g}$, total gula 58.30\%, aktivitas antioksidan $965.3 \mathrm{ppm}$, dan $\mathrm{pH}$ 2.7. Seduhannya memiliki karakteristik warna ( $L^{*} 38.9$; $a+12.9$; $\left.b+5.6\right)$, TPT $14.27 \%$, vitamin $C$ $14.08 \mathrm{mg} / 100 \mathrm{~g}$, total gula $17.06 \%$, aktivitas antioksidan $3370 \mathrm{ppm}$, dan $\mathrm{pH} 2.9$
\end{abstract}

Kata kunci : Citrus infused honey tea, Infusing, Madu, Organoleptik, Rosela

\begin{abstract}
Citrus infused honey tea in Indonesia is a product of honey processing innovation which is expected to provide greater benefits than existing others derivatived honey products. Roselle added to improve appearance and give the red color products. The purpose of this study is to determine the effect and the combination of concentration of rosela and the period of infusing in producing citrus infused honey tea and to know the physicochemical characteristics of the best treatment of citrus infused honey tea. This study was using Complete Random Design method (RAL) factorial with two factors, namely concentration of roselle $(10 \%, 15 \%$, and $20 \%)$, and period of infusing (1 day and 7 days). The best treatment is determined with Zeleny method. The result showed that concentration of roselle, period of infusing, and its interaction influences significantly the organoleptic parametrics. The best treatment was obtained by roselle concentration of $15 \%$ and the period of infusing for 7 days. Characteristics of the best treatment of citrus infused honey tea consists of color ( $\left.L^{*} 28.3 ; a+17.6 ; b+3.9\right)$, TDS $66.27 \%$, viscosity $11.210 \mathrm{cps}$, water content $30.37 \%$, vitamin C $35.66 \mathrm{mg} / 100 \mathrm{~g}$, total sugar $58.30 \%$, antioxidant activity $965.3 \mathrm{ppm}$, and $\mathrm{pH}$ 2.7. The infusion has characteristics of colors $\left(L^{*} 38.9 ; a+12.9 ; b+5.6\right)$, TDS $14.27 \%$, vitamin C $14.08 \mathrm{mg} / 100 \mathrm{~g}$, total sugar $17.06 \%$, antioxidant activity $3370 \mathrm{ppm}$, and $\mathrm{pH} 2.9$
\end{abstract}

Keywords: Citrus infused honey tea, Honey, Infusing, Organoleptic, Roselle 


\section{PENDAHULUAN}

Madu merupakan produk cairan kental dan manis yang dihasilkan oleh lebah madu dari nektar atau sekresi bunga atau sekresi serangga yang diletakkan pada bagian tanaman yang selanjutnya dikumpulkan, diubah dan disimpan oleh lebah dalam sarangnya (Codex Stan, 1981). Kementerian Lingkungan Hidup dan Kehutanan (2015) menyatakan bahwa total produksi madu di Indonesia mencapai 5000 ton pada tahun 2014. Namun, jumlah produksi madu tersebut belum diimbangi dengan pemanfaatan yang maksimal. Penggunaan serta teknik pengolahan madu di Indonesia masih terbatas. Selain itu, jenis produk olahan madu yang beredar di Indonesia juga masih sangat minim. Madu hanya dijual dalam bentuk madu murni, madu campuran, dan minuman madu Hal tersebut membuat madu terkesan sebagai produk yang monoton, sehingga berpengaruh pada tingkat konsumsi madu di Indonesia. Tingkat konsumsi madu masyarakat Indonesia masih tergolong rendah, yaitu sekitar 10-15 g/orang/tahun, atau setara 1 sendok makan/orang/tahun (Novandra dan Widnyana, 2013; Suhesti dan Hadinoto, 2015). Inovasi pengolahan madu diperlukan untuk menghasilkan produk yang dapat dikonsumsi dan memberikan manfaat yang lebih besar, sehingga dapat meningkatkan konsumsi madu di Indonesia, yang salah satunya adalah citrus infused honey tea (CIHT).

Citrus infused honey tea belum memiliki definisi standar dari Codex karena merupakan adopsi minuman tradisional dari Korea yang dikenal dengan nama Yujacha. Yujacha adalah teh tradisional Korea yang terbuat dari jeruk yang diambil slurry dan potongan tipis dari kulitnya, kemudian dikombinasikan dengan madu atau gula dan dilakukan proses infusing selama minimal tujuh hari (Imatome-Yun, 2012; General Ming's, 2013; Brigand dan Nahon, 2016). Penggunaan bahan baku khas Indonesia seperti jeruk manis, kayu manis, dan rosela diharapkan dapat memberikan rasa khas Indonesia meningkatkan kualitas produk citrus infused honey tea.

Jeruk manis (Citrus sinensis L.) memiliki rasa manis, vitamin $C$, serta kandungan pektin pada kulitnya, sedangkan kayu manis (Cinnamomum burmanii) memiliki aroma harum, menyengat dan rasa yang manis dapat dimanfaatkan untuk pembuatan citrus in- fused honey tea. Penambahan rosela (Hibiscus sabdariffa L.) berpotensi sebagai pewarna merah alami yang berasal dari antosianin dan rasa masam yang unik hasil perpaduan dari berbagai jenis asam. Komposisi kimia dari madu, jeruk manis, kayu manis dan rosela dilaporkan berpotensi sebagai antioksidan tubuh (Gheldof dan Engeseth, 2002; Kumalaningsih, 2006; Lee dan Shibatomo, 2012; Tsai et al., 2002), dan berhubungan sinergis dalam memberikan sifat organoleptik dan meningkatkan aktifitas antioksidan (Yulia et al., 2011; Yulia et al., 2013; Hastuti, 2012).

Uji organoleptik perlu dilakukan untuk mendapatkan produk yang dapat di terima konsumen, yang melibatkan panelis dengan parameter warna, rasa, aroma, dan kenampakan (Karagül-Yüceer et al., 1999; Frewer et al., 2011; Šebjan dan Tominc, 2016). Analisis kimia dan fisik perlu dilakukan setelah mendapatkan perlakuan terbaik secara organoleptik, untuk memberikan informasi tentang karakteristik produk citrus infused honey tea.

\section{BAHAN DAN METODE}

\begin{abstract}
Alat
Peralatan yang digunakan dalam pembuatan citrus infused honey tea adalah timbangan, lemari pendingin, kompor, panci, pengaduk, baskom, dan jar kaca. Peralatan analisis adalah timbangan analitik (Mettler Toledo Swiss Brand), color reader (Konica Minolta USA), spektrofotometer (LabMed Inc USA), hand refraktometer (Atago Japan), viscometer (Elcometer UK), $\mathrm{pH}$ meter, vortex, shaker, dan glassware.

\section{Bahan}

Bahan pembuatan citrus infused honey tea adalah madu karet dari peternakan madu hutan Pati, jeruk manis dari perkebunan jeruk Selorejo Malang, kayu manis batang, gula dan garam dari supermarket Giant, dan rosela kering dari depot jamu di Pasar Besar, Malang. Bahan kimia yang digunakan adalah larutan DPPH 0.2 mM (Sigma-Aldrich), etanol 96\% (Merck), toluene (Merck), 2.6 diklorofenol (Merck), $\mathrm{HPO}_{3}$ (Merck), asam asetat glasial (Merck), $\mathrm{NaHCO}_{3}$ (Merck), Anthrone (Merck), $\mathrm{H}_{2} \mathrm{SO}_{4}$ (Merck), Pb-asetat (Merck), $\mathrm{Na}$-oksalat (Merck), $\mathrm{CaCO}_{3}$ (Merck), buffer 4 dan 7 (Merck), hidrobat dan akuades.
\end{abstract}




\section{Metode}

\section{Penelitian Pendahuluan}

Penyeleksian terhadap 5 konsentrasi rosela awal yaitu $5 \%, 10 \%, 15 \%, 20 \%$, dan $25 \%$ menggunakan analisis warna dan $\mathrm{pH}$ yang bertujuan untuk mengetahui intensitas warna merah dan rasa asam pada produk citrus infused honey tea, sehingga dapat dipilih 3 konsentrasi rosela yang akan digunakan pada penelitian utama.

\section{Pembuatan Citrus Honey Tea}

Jeruk manis dicuci dengan garam kemudian dikupas dan dipisahkan kulit dan slury-nya. Kulit jeruk dipotong dengan ukuran $2 \mathrm{~mm}$ x $2 \mathrm{~mm}$, kemudian direndam dalam air yang ditambahkan garam dengan perbandingan 18:1 (b/v) selama 1 jam. Kulit jeruk direbus dengan larutan garam selama 3-5 menit, kemudian di cuci dengan air mengalir dan tiriskan. Slurry jeruk manis dipisahkan dari sekatnya dan dicampur dengan kulit jeruk manis dengan perbandingan 1:5 (b/b). Gula dilarutkan dalam air dengan perbandingan 1:2 (b/v), dimasak hingga mencair, kemudian ditambahkan kayu manis $1 \%$ (b/b), kulit jeruk, slury jeruk, hingga menjadi marmalade jeruk yang kental. Marmalade jeruk dimasukkan dalam jar dan dibiarkan dingin, kemudian ditambahkan madu dengan perbandingan marmalade : madu $(1: 2 \mathrm{~b} / \mathrm{b})$.

\section{Pembuatan Citrus Infused Honey Tea}

Kelopak bunga rosela kering direndam dalam air panas suhu $60^{\circ} \mathrm{C}$ selama 2 menit, kemudian dipotong dengan ukuran 2 $\mathrm{mm} \times 2 \mathrm{~mm}$. Rosela yang telah dipotong selanjutnya ditimbang sesuai konsentrasi yang ditentukan $10 \%, 15 \%$, dan $20 \%$ (b/b), dan dimasukkan ke dalam jar kaca yang telah berisi citrus honey tea. Citrus honey tea yang telah ditambahkan rosela kemudian dilakukan infusing selama 1 hari dan 7 hari.

\section{Rancangan Percobaan}

Penelitian menggunakan Rancangan Acak Lengkap (RAL) faktorial dengan dua faktor perlakuan, yaitu konsentrasi rosela yang terdiri dari 3 level (R1 $=10 \% ; R 2=15 \%$; $\mathrm{R} 3=20 \%(\mathrm{~b} / \mathrm{b})$ ), dan lama infusing yang terdiri dari 2 level (1 hari dan 7 hari), sehingga diperoleh 6 kombinasi perlakuan yang akan di uji organoleptik. Penelitian ini melibatkan 110 panelis tidak terlatih. Uji oganoleptik menggunakan metode hedonik (Rahayu, 2001; Ruark et al., 2016), yang meliputi ting- kat kesukaan warna, kekeruhan, aroma, rasa, dan keluruhan serta metode mutu hedonik (Bambang et al., 1988) meliputi tingkat kemerahan, kejernihan, aroma, dan kemanisan.

Parameter kimia dan fisik yang di analisis pada perlakuan terbaik uji organoleptik adalah aktivitas antioksidan (Molyneux, 2004), kadar air (Sudarmadji et al., 1997), vitamin C (Sudarmadji et al., 1997), pH (Sudarmadji et al., 1997), total gula (Apriyantono et al., 1989), warna (Yuwono dan Susanto, 1998), total padatan terlarut (Apriyantono et al., 1989) dan viskositas (Yuwono dan Susanto, 1998) pada pekatan dan seduhan produk citrus infused honey tea.

\section{Analisis Data}

Data hasil penelitian di analisis variannya (ANOVA). Apabila dari hasil uji terdapat perbedaan, maka dilanjutkan dengan BNT atau DMRT dengan taraf 5\% untuk melihat perbedaan antar perlakuan. Pemilihan perlakuan terbaik uji organoleptik menggunakan metode multiple attribute (Zeleny, 1982).

\section{HASIL DAN PEMBAHASAN}

\section{Karakteristik Bahan Baku Madu}

Berdasarkan karakteristik bahan baku madu karet dibandingkan madu literatur seperti yang ditunjukkan pada Tabel 1, dapat diketahui bahwa madu karet yang digunakan pada penelitian ini sudah sesuai dengan peraturan SNI yang beredar di Indonesia. Beberapa perbedaan karakteristik antara madu karet dengan literatur dikarenakan masingmasing sumber nektar madu memiliki karakteristik yang berbeda (Lower, 1987; Sanz et al., 2005; Ball, 2007) . Hal ini didukung oleh Sihombing (2005) yang menyatakan bahwa komponen kimia dalam madu dipengaruhi oleh beberapa faktor diantaranya jenis dan jumlah nektar bunga, proses pematangan madu, perbedaan topografi, lebah yang menghasilkan madu serta cara pengolahan dan penyimpanan madu.

\section{Penelitian Pendahuluan}

Berdasarkan analisis warna dan $\mathrm{pH}$ pada penelitian pendahuluan, seperti yang tertera pada Tabel 2, dihasilkan tiga konsentrasi rosela terbaik, yaitu konsentrasi rosela $10 \%, 15 \%$, dan $20 \%$ yang akan dikombinasikan dengan lama infusing 1 hari dan 7 hari. 
Jurnal Teknologi Pertanian Vol. 18 No. 1 [April 2017] 21-32

Inovasi Produk Citrus Infused Honey Tea dengan Penambahan Rosela [Murtini dkk.]

Tabel 1. Karakteristik bahan baku madu

\begin{tabular}{lcc}
\hline Parameter & Hasil & Literatur \\
\hline Nilai L & $34.8 \pm 0.267$ & \\
Nilai a & $+6.4 \pm 0.260$ & Amber $^{\mathrm{a}}$ \\
Nilai b & $+20.7 \pm 0.208$ & \\
TPT ( ${ }^{\circ}$ Brix) & $73 \pm 0.000$ & $82^{\mathrm{a}}$ \\
Viskositas (cps) & $7.600 \pm 0.000$ & $10.000^{\mathrm{a}}$ \\
pH & $3.87 \pm 0.033$ & $3.42-6.10^{\mathrm{b}}$ \\
Kadar air (\%) & $20.21 \pm 0.337$ & Maks $22^{\mathrm{b}}$ \\
Aktivitas antioksidan (ppm) & $1471.11 \pm 2.004$ & $1500^{\mathrm{a}}$ \\
Vitamin C (mg/100 g) & $0.305 \pm 0.000$ & $0.5^{\mathrm{c}}$ \\
Total gula (\%) & $69.88 \pm 1.182$ & $82.12^{\mathrm{c}}$
\end{tabular}

Keterangan : data adalah rerata dari 3 kali pengulangan \pm standard error; Sihombing, 2005 (a); BSN, 2013 (b); USDA, 2016 (c)

Tabel 2. Hasil analisis warna dan $\mathrm{pH}$ dengan berbagai konsentrasi rosela

\begin{tabular}{lcc}
\hline Perlakuan & Nilai a & pH \\
\hline Rosela 5\% & $+9.4 \pm 0.088^{\mathrm{a}}$ & $3.7 \pm 0.000^{\mathrm{a}}$ \\
Rosela 10\% & $+11.4 \pm 0.346^{\mathrm{b}}$ & $3.4 \pm 0.000^{\mathrm{b}}$ \\
Rosela 15\% & $+13.6 \pm 0.384^{\mathrm{c}}$ & $3.1 \pm 0.000^{\mathrm{c}}$ \\
Rosela 20\% & $+16.2 \pm 0.153^{\mathrm{d}}$ & $2.8 \pm 0.067^{\mathrm{d}}$ \\
Rosela 25\% & $+16.9 \pm 0.088^{\mathrm{d}}$ & $2.6 \pm 0.067^{\mathrm{e}}$
\end{tabular}

Keterangan : data adalah rerata dari 3 kali pengulangan \pm standard error. Notasi yang berbeda menunjukkan perlakuan berbeda nyata $(\alpha=0.05)$

Tabel 3. Data hasil uji organoleptik hedonik dari berbagai konsentrasi rosela

\begin{tabular}{lccccc}
\hline Perlakuan & Warna & Kekeruhan & Aroma & Rasa & Keseluruhan \\
\hline Rosela 10\% & $2.43 \pm 0.065^{\mathrm{a}}$ & $2.51 \pm 0.058^{\mathrm{a}}$ & $3.07 \pm 0.059^{\mathrm{a}}$ & $3.52 \pm 0.056^{\mathrm{b}}$ & $3.10 \pm 0.057^{\mathrm{a}}$ \\
Rosela 15\% & $3.25 \pm 0.053^{\mathrm{b}}$ & $3.08 \pm 0.047^{\mathrm{b}}$ & $3.40 \pm 0.051^{\mathrm{c}}$ & $3.70 \pm 0.056^{\mathrm{c}}$ & $3.48 \pm 0.046^{\mathrm{c}}$ \\
Rosela 20\% & $3.90 \pm 0.062^{\mathrm{c}}$ & $3.49 \pm 0.060^{\mathrm{c}}$ & $3.17 \pm 0.060^{\mathrm{b}}$ & $2.70 \pm 0.072^{\mathrm{a}}$ & $3.13 \pm 0.060^{\mathrm{b}}$ \\
\hline
\end{tabular}

Keterangan : data adalah rerata dari 110 kali pengulangan \pm standard error. Notasi yang berbeda menunjuk-

kan perlakuan berbeda nyata $(\alpha=0.05)$

Tabel 4. Data hasil uji organoleptik hedonik dari berbagai lama infusing

\begin{tabular}{lcc}
\hline Perlakuan & Warna & Kemanisan \\
\hline 1 Hari & $2.95 \pm 0.059^{\mathrm{a}}$ & $3.48 \pm 0.046^{\mathrm{b}}$ \\
7 Hari & $3.43 \pm 0.056^{\mathrm{b}}$ & $3.13 \pm 0.062^{\mathrm{a}}$
\end{tabular}

Keterangan : data adalah rerata dari 110 kali pengulangan \pm standard error. Notasi yang berbeda menunjukkan perlakuan berbeda nyata $(\alpha=0.05)$

Tabel 5. Data hasil uji organoleptik mutu hedonik dari berbagai konsentrasi rosela

\begin{tabular}{lllll}
\hline Perlakuan & Kemerahan & Kejernihan & Aroma & Kemanisan \\
\hline Rosela 10\% & $2.20 \pm 0.056^{\mathrm{a}}$ & $2.74 \pm 0.048^{\mathrm{a}}$ & $2.25 \pm 0.054^{\mathrm{a}}$ & $3.62 \pm 0.050^{\mathrm{c}}$ \\
Rosela 15\% & $3.15 \pm 0.045^{\mathrm{b}}$ & $2.91 \pm 0.045^{\mathrm{b}}$ & $2.80 \pm 0.055^{\mathrm{b}}$ & $3.09 \pm 0.049^{\mathrm{b}}$ \\
Rosela 20\% & $4.25 \pm 0.052^{\mathrm{c}}$ & $3.08 \pm 0.051^{\mathrm{c}}$ & $3.00 \pm 0.057^{\mathrm{c}}$ & $2.18 \pm 0.049^{\mathrm{a}}$
\end{tabular}

Keterangan : data adalah rerata dari 110 kali pengulangan \pm standard error. Notasi yang berbeda menunjukkan perlakuan berbeda nyata $(\mathrm{a}=0.05)$ 
Konsentrasi rosela 5\% tidak dipilih karena memiliki intensitas warna merah paling rendah, sedangkan konsentrasi rosela 25\% tidak dipilih karena memiliki $\mathrm{pH}$ yang terlalu rendah, sehingga rasa produk terlalu asam dan intensitas warna merah yang tidak berbeda nyata dengan konsentrasi $20 \%$.

\section{Karakteristik Organoleptik Hedonik}

Uji organoleptik hedonik seduhan CIHT dilakukan untuk mengetahui tingkat kesukaan konsumen terhadap produk dari tingkat warna, kekeruhan, aroma, rasa, dan keseluruhan.

\section{Faktor Konsentrasi Rosela}

Berdasarkan data uji organoleptik hedonik dari berbagai konsentrasi rosela pada Tabel 3, dapat diketahui bahwa panelis lebih menyukai seduhan CIHT yang berwarna merah. Semakin tinggi konsentrasi rosela maka tingkat kesukaan panelis semakin tinggi. Warna merah tersebut berasal pigmen antosianin dengan total sebesar 445 mg/100 g berat kering (Chumsri et al., 2008). Panelis juga lebih menyukai seduhan CIHT yang semakin keruh (Utama-ang et al., 2007; Theron et al., 2014). Meningkatnya tingkat kesukaan panelis diikuti dengan semakin tinggi konsentrasi rosela. Peningkatan kesukaan panelis disebabkan oleh warna merah yang ditimbulkan oleh rosela sehingga menutupi kekeruhan seduhan CIHT. Kekeruhan tersebut berasal dari asamasam organik, mineral, dan pigmen rosela (Tsai et al., 2002), dan padatan tidak terlarut sebesar 37.74\% (Shoosh, 1997). Panelis lebih menyukai seduhan CIHT dengan intensitas aroma sedang. Tingkat kesukaan panelis menurun pada intensitas aroma yang lemah dan terlalu kuat. Aroma rosela berasal dari senyawa volatil seperti 1-octen3-ol, furfural dan 5-metil furfural (RamírezRodrigues et al., 2011) terpen, aldehid, ester, dan hidrokarbon (Gonzales-Palomares et al., 2009). Senyawa volatil jeruk manis

Tabel 6. Data hasil uji organoleptik mutu hedonik dari berbagai lama infusing

\begin{tabular}{lcl}
\hline Perlakuan & Warna & Kemanisan \\
\hline 1 Hari & $2.95 \pm 0.059^{\mathrm{a}}$ & $3.48 \pm 0.046^{\mathrm{b}}$ \\
7 Hari & $3.43 \pm 0.056^{\mathrm{b}}$ & $3.13 \pm 0.062^{\mathrm{a}}$ \\
\hline
\end{tabular}

Keterangan : data adalah rerata dari $110 \mathrm{kali}$ pengulangan \pm standard error. Notasi yang berbeda menunjukkan perlakuan berbeda nyata $(\alpha=0.05)$

Tabel 7. Karakteristik fisik perlakuan terbaik citrus infused honey tea

\begin{tabular}{lcc}
\hline Analisis & Pekatan & Seduhan \\
\hline Nilai L* & $28.3 \pm 0.549$ & $38.9 \pm 0.145$ \\
Nilai a & $+17.6 \pm 0.133$ & $+12.9 \pm 0.208$ \\
Nilai b & $+3.9 \pm 0.203$ & $+5.6 \pm 0.120$ \\
Total padatan terlarut & $66.27 \pm 0.067^{\circ}$ Brix & $14.27 \pm 0.067^{\circ}$ Brix \\
Viskositas & $11210 \pm 5.774 \mathrm{cps}$ & - \\
Keterangan : data adalah rerata dari 3 kali pengulangan \pm standard error. Notasi yang berbeda menunjukkan \\
perlakuan berbeda nyata ( $a=0.05)$
\end{tabular}

Tabel 8. Karakteristik kimia perlakuan terbaik citrus infused honey tea

\begin{tabular}{lcc}
\hline Analisis & Pekatan & Seduhan \\
\hline $\mathrm{pH}$ & $2.7 \pm 0.033$ & $2.9 \pm 0.033$ \\
Kadar air & $30.37 \pm 0.461 \%$ & - \\
Vitamin C & $35.66 \pm 0.939 \mathrm{mg} / 100 \mathrm{~g}$ & $14.08 \pm 0.000 \mathrm{mg} / 100 \mathrm{~g}$ \\
Total gula & $58.30 \pm 0.882 \%$ & $17.06 \pm 0.807 \%$ \\
Aktivitas antioksidan & $965.3 \pm 1.225 \mathrm{ppm}$ & $3370 \pm 4.163 \mathrm{ppm}$ \\
\hline
\end{tabular}

Keterangan : data adalah rerata dari $3 \mathrm{kali}$ pengulangan \pm standard error. Notasi yang berbeda menunjukkan perlakuan berbeda nyata $(\alpha=0.05)$ 
berasal dari $1.5 \%$ minyak atsiri (Verzera et al., 2014; Hashtjin dan Abbasi, 2015;) dan aroma kayu manis dari minyak atsiri jenis cinnamaldehyde dan eugenol (Peter, 2001; Chen et al., 2006; Ribeiro-Santos et al., 2017) yang dapat meningkatkan intensitas aroma CIHT.

Perpaduan rasa manis dan masam yang seimbang pada seduhan CIHT lebih disukai panelis. Konsentrasi rosela yang terlalu tinggi akan menurunkan tingkat kesukaan panelis karena membuat rasa yang sangat masam. Rasa asam rosela berasal dari hasil perpaduan berbagai jenis asam seperti asam askorbat, asam sitrat, asam malat dan asam glikolik (Mardiah et al., 2009; Da-CostaRocha et al., 2014; Farag et al., 2015). Faktor lainnya berasal dari rasa marmalade yang terbuat dari jeruk dan kayu manis yang bercampur dengan madu.

Secara keseluruhan panelis lebih menyukai seduhan CIHT konsentrasi rosela $15 \%$. Konsentrasi rosela $20 \%$ memiliki intensitas aroma dan rasa yang terlalu tinggi, sehingga kurang disukai. Konsentrasi rosela $10 \%$ memiliki intensitas warna, kekeruhan, aroma, dan rasa yang rendah sehingga kurang disukai oleh panelis dibandingkan dengan konsentrasi rosela $15 \%$ dan $20 \%$.

\section{Faktor Lama Infusing}

Berdasarkan data hasil uji organoleptik hedonik dari berbagai lama infusing pada Tabel 4, dapat diketahui bahwa panelis lebih menyukai seduhan CIHT hasil lama infusing 7 hari. Semakin lama proses infusing akan membuat warna seduhan CIHT menjadi semakin merah dan meningkatkan kesukaan panelis. Antosianin merupakan pigmen yang larut dalam air yang menghasilkan warna dari merah hingga biru (Moss, 2002; Cui et al., 2015) dan terdapat dalam vakuola sel bagian tanaman (Kimbal, 1993; Padayachee et al., 2012; Bautista-Ortín et al., 2016; Cui et al., 2016). Semakin lama infusing, maka dinding sel tanaman akan mengalami kerusakan, sehingga komponen dalam sel termasuk antosianin akan keluar dan bercampur dengan madu sehingga warna seduhan CIHT semakin merah.

Lama infusing 7 hari membuat rasa seduhan CIHT menjadi semakin masam dan menurunkan tingkat kesukaan panelis. Faktor lainnya berasal dari rasa marmalade jeruk dan kayu manis yang semakin terekstrak ke dalam madu. Perlakuan pengolahan memungkinkan untuk merusak dinding sel dan subseluler tanaman herbal untuk membebaskan komponen-komponen dalam sel seperti asam organik dalam jumlah yang besar, sehingga menghasilkan intensitas rasa produk yang tinggi (Khatun et al., 2006). Hasil penelitian tersebut didukung oleh penelitian Mahardika (2014) yang menyebutkan bahwa konsumen lebih menyukai rasa manis pada minuman sari rosela berkarbonasi, sehingga dilakukan uji penurunan tingkat keasaman.

Tingkat kesukaan keseluruhan hasil lama infusing 7 hari lebih disukai oleh panelis. Hasil tersebut karena lama infusing 1 hari menghasilkan intensitas warna, kekeruhan dan aroma lebih rendah dibandingkan dengan lama infusing 7 hari. Lama infusing 1 hari hanya unggul dari tingkat kesukaan rasa seduhan CIHT karena kecenderungan panelis lebih menyukai rasa manis daripada masam.

\section{Karakteristik Organoleptik Mutu Hedonik}

Uji organoleptik CIHT dilakukan untuk menyatakan kesan pribadi panelis tentang baik atau buruk (kesan mutu hedonik) terhadap produk pangan dengan empat parameter yaitu tingkat kemerahan, kejernihan, aroma, dan kemanisan.

\section{Faktor Konsentrasi Rosela}

Berdasarkan data hasil uji organoleptik mutu hedonik dari berbagai konsentrasi rosela pada Tabel 5, dapat diketahui bahwa semakin tinggi konsentrasi rosela, maka tingkat kemerahan seduhan CIHT semakin tinggi. Warna merah tersebut berasal dari kandungan antosianin pada rosela dengan total kandungan sebesar 445 $\mathrm{mg} / 100 \mathrm{~g}$ berat kering (Chumsri et al., 2008). Menurut penilaian panelis semakin tinggi konsentrasi rosela maka semakin tinggi tingkat kejernihan seduhan CIHT yang disebabkan oleh warna merah dari rosela, sehingga menutupi kekeruhan seduhan CIHT. Kekeruhan tersebut berasal dari asamasam organik, mineral dan pigmen rosela (Tsai et al., 2002).

Menurut penilaian panelis semakin tinggi konsentrasi rosela maka semakin tinggi intensitas aroma seduhan CIHT. Aroma rosela berasal dari senyawa volatil seperti 1-octen-3-ol, furfural dan 5-metil furfural (Ramírez-Rodrigues et al., 2011) terpen, aldehid, ester dan hidrokarbon (GonzalesPalomares et al., 2009). Senyawa-senyawa 
volatil jeruk manis berasal dari $1.5 \%$ minyak atsiri (Da-Costa-Rocha et al., 2014; Farag et al., 2015) dan aroma kayu manis dari minyak atsiri jenis cinnamaldehyde dan eugenol (Peter, 2001) yang dapat meningkatkan intensitas aroma CIHT.

Menurut penilaian panelis semakin tinggi konsentrasi rosela maka tingkat kemanisan seduhan CIHT akan semakin rendah karena direduksi oleh rasa asam rosela. Rosela mengandung asam hibiskus, asam protokatekin, asam askorbat, malat dan hibiskat (Herrera-Arellano et al., 2004) dengan total citric acid berkisar $17.43-21.84 \%$, sedangkan total hibiscic acid berkisar 22.41-27.88\% (Shoosh, 1997). Hasil penelitian ini didukung oleh Nidya (2009) yang menghasilkan semakin banyak rosela yang digunakan, maka tingkat kemanisan marshmallow akan semakin menurun.

\section{Faktor Lama Infusing}

Berdasarkan data hasil uji organoleptik mutu hedonik dari berbagai lama infusing pada Tabel 6, dapat diketahui bahwa semakin lama infusing maka tingkat kemerahan seduhan CIHT semakin tinggi. Selain itu, menurut Kimbal (1993) antosianin terdapat dalam vakuola sel bagian tanaman. Semakin lama infusing maka dinding sel tanaman akan mengalami kerusakan sehingga komponen dalam sel termasuk antosianin akan keluar dan bercampur dengan madu sehingga warna seduhan CIHT semakin merah.

Semakin lama proses infusing maka asam-asam organik rosela semakin terekstrak ke dalam madu, sehingga tingkat kemanisan seduhan CIHT semakin rendah. Faktor lainnya berasal dari rasa marmalade jeruk dan kayu manis yang semakin terekstrak ke dalam madu yang menambah tingkat kemanisan CIHT. Perlakuan pengolahan memungkinkan merusak dinding sel dan subseluler dari tanaman herbal untuk membebaskan komponen dalam sel seperti asam organik dalam jumlah yang besar sehingga menghasilkan tingkat keasaman yang tinggi (Khatun et al., 2006; Farzaneh dan Carvalho, 2015; Radice et al., 2016).

\section{Penentuan Perlakuan Terbaik}

Penilaian perlakuan terbaik terhadap parameter organoleptik seduhan citrus infused honey tea menggunakan metode multiple attribute seperti yang ditunjukkan pada Tabel 7. Menurut panelis perlakuan terbaik seduhan CIHT adalah konsentrasi rosela $15 \%$ dan lama infusing 7 hari. Perlakuan terbaik CIHT memiliki skor kesukaan warna $3.39 \pm 0.081$ (suka), kekeruhan $3.11 \pm 0.061$ (suka), aroma $3.50 \pm 0.062$ (suka), rasa $3.62 \pm$ 0.089 (suka), keseluruhan $3.69 \pm 0.068$ (suka), tingkat kemerahan $3.26 \pm 0.064$ (merah), kejernihan $3.00 \pm 0.067$ (agak jernih), aroma $2.82 \pm 0.086$ (agak menyengat) dan kemanisan $2.22 \pm 0.085$ (agak manis dan agak masam).

\section{Karakteristik Fisik Perlakuan Terbaik}

Analisis fisik perlakuan terbaik uji organoleptik citrus infused honey tea pada Tabel 8, menunjukkan bahwa warna seduhan CIHT memiliki tingkat kecerahan (nilai L*) dan tingkat kekuningan (nilai b) lebih tinggi daripada pekatannya. Sebaliknya, tingkat kemerahan (nilai a) dan total padatan terlarut seduhan lebih rendah daripada pekatannya. Hal ini dikarenakan adanya penambahan air pada seduhan sebanyak 3 kali lipat dari pekatan. Air merupakan pelarut universal karena dapat melarutkan berbagai komponen dengan ikatan yang kuat antara molekul air dan komponen lain tersebut (Pohorille, 2005; Ma et al., 2015).

Berdasarkan hasil analisis fisik dapat diketahui bahwa pekatan maupun seduhan citrus infused honey tea memiliki warna merah yang berasal dari kandungan antosianin dengan total kandungan sebesar $445 \mathrm{mg} / 100$ g berat kering (Chumsri et al., 2008; AlHafez et al., 2014; Zhang dan Ruan, 2016). Total padatan terlarut pada pekatan dan seduhan CIHT berasal dari madu dengan kadar gula tinggi dan adanya penambahan bahanbahan lain seperti jeruk, kayu manis, dan rosela. Ranken dan Kill (1997) menyatakan bahwa komponen-komponen yang terukur sebagai total padatan terlarut adalah asamasam organik, sukrosa, gula reduksi, garam dan protein. Nilai viskositas pekatan CIHT menunjukkan bahwa CIHT memiliki tingkat kekentalan tinggi yang dipengaruhi adanya penambahan zat yang banyak mengandung gula (Winarno, 2008; Rieder et al., 2015; Tau dan Gunasekaran, 2016).

\section{Karakteristik Kimia Perlakuan Terbaik}

Analisis kimia perlakuan terbaik uji organoleptik citrus infused honey tea pada Tabel 8, menunjukkan bahwa nilai $\mathrm{pH}$ dan aktivitas antioksidan pekatan lebih rendah daripada seduhannya. Semakin rendah $\mathrm{pH}$ menunjukkan semakin asam produk 
pangan tersebut. Semakin rendah nilai aktivitas antioksidan, maka semakin tinggi kualitas produk pangan sebagai antioksidan. Sebaliknya, kadar vitamin C dan total gula seduhan lebih rendah dibandingkan dengan pekatannya. Hasil tersebut dikarenakan adanya penambahan air pada seduhan sebanyak 3 kali lipat dari pekatan. Air merupakan pelarut universal karena dapat melarutkan berbagai komponen dengan ikatan yang kuat antara molekul air dan komponen lainnya (Pohorille, 2005).

Berdasarkan hasil analisis kimia maka dapat diketahui bahwa citrus infused honey tea termasuk dalam produk pangan asam karena mengandung rosela yang memiliki pH rendah yaitu 1.4 (Farida et al., 2013; Fasoyiro, 2014; Abbas et al., 2016). Nilai $\mathrm{pH}$ juga berpengaruh terhadap stabilitas warna merah yang dihasilkan. Pada $\mathrm{pH} 1$ warna antosianin yang ditunjukkan adalah merah, $\mathrm{pH} 4$ biru kemerahan, $\mathrm{pH} 6$ ungu, pH 8 biru, dan pH 12 menunjukkan warna hijau (Richana, 2009; Padayachee et al., 2012; Cui et al., 2016). Analisis kadar air pekatan CIHT menunjukkan bahwa CIHT termasuk dalam produk Intermediate Moisture Food (IMF) karena memiliki kadar air 15-50\% (Nopwinyuwong et al., 2010). Kadar air tersebut memungkinkan CIHT memiliki umur simpan yang panjang. Kadar vitamin C CIHT diduga mengalami penurunan yang disebabkan oleh berbagai proses pengolahan seperti pencucian, pemotongan dan pemanasan (Mentari dan Susanto, 2014; Jeney-Nagymate dan Fodor, 2008; Uckiah et al., 2009). Vitamin $C$ sangat mudah rusak selama proses penyimpanan dan pengolahan makanan sekitar $80 \%$ (Uckiah et al., 2009; Rigaux et al., 2016). Kadar total gula CIHT sebagian besar berasal dari madu yang terdiri dari $85-90 \%$ monosakarida fruktosa dan glukosa (Sihombing, 2005; Bogdanov, 2009; Alvarez-Suarez et al., 2010; El Sohaimy et al., 2015). Nilai aktivitas antioksidan pekatan CIHT dapat berpotensi sebagai antioksidan karena berkisar antara 300-1000 ppm (Molyneux, 2004), serta berasal dari bahan-bahan baku penyusunnya seperti madu yang terdiri dari flavonoid, asam fenolik, beberapa enzim seperti glukosa oksidase dan katalase, turunan karotenoid, vitamin $C$ dan asam organik yang berperan sebagai antioksidan (Gheldof dan Engeseth, 2002). Rosela juga berperan dalam menyumbangkan antioksidan pada CIHT karena mengandung antosianin (Tsai et al., 2002). Jeruk mengandung vitamin $C$ yang tergolong dalam antioksidan sekunder dan oxygen scavanger (Kurowska dan Manthey, 2004), dan kayu manis memiliki komponen aktif cinnamaldehyde yang merupakan turunan senyawa fenol yang berfungsi sebagai antioksidan yang menangkap radikal bebas dan melindungi sel dari mutagenesis (Lee dan Shibatomo, 2002; Gan et al., 2009; Guzman, 2014).

\section{SIMPULAN}

Berdasarkan penelitian yang telah dilakukan dapat disimpulkan bahwa konsentrasi rosela, lama infusing, dan interaksi keduanya berpengaruh nyata terhadap parameter organoleptik seduhan citrus infused honey tea. Berdasarkan metode multiple attribute perlakuan terbaik citrus infused honey tea adalah konsentrasi rosela 15\% dan lama infusing 7 hari. Citrus infused honey tea perlakuan terbaik memiliki karakteristik tingkat kecerahan (nilai $L^{*}$ ) $28.3 \pm 0.549$, tingkat kemerahan (nilai $\mathrm{a}+$ ) $17.6 \pm 0.133$, tingkat kekuningan (nilai $b+$ ) $3.9 \pm 0.203$, total padatan terlarut $66.27 \pm 0.067^{\circ}$ Brix, viskositas 11210 \pm 5.774 cps, pH $2.7 \pm 0.033$, kadar air 30.37 $\pm 0.461 \%$, vitamin C $35.66 \pm 0.882 \mathrm{mg} / 100 \mathrm{~g}$, total gula $58.30 \pm 0.882 \%$, serta aktivitas antioksidan $965.3 \pm 1.225 \mathrm{ppm}$. Seduhan citrus infused honey tea perlakuan terbaik memiliki karakteristik tingkat kecerahan (nilai L*) 38.9 \pm 0.145 , tingkat kemerahan (nilai a+) 12.9 \pm 0.208 , tingkat kekuningan (nilai $b+$ ) $5.6 \pm$ 0.120 , total padatan terlarut $14.27 \pm 0.067$ ${ }^{\circ}$ Brix, pH $2.9 \pm 0.033$, vitamin C 14.08 mg/100 $\mathrm{g}$, total gula $17.06 \pm 0.807 \%$, serta aktivitas antioksidan $3370 \pm 4.163 \mathrm{ppm}$.

\section{DAFTAR PUSTAKA}

Abbas, R, K, Fadlelmula, A, A, Elsharbasy, F, S. 2016. Effect of storage duration and cultivars on chemical constituents of roselle (Hibiscussabdariffa L.) undergrowing conditions of sudan. Journal of Chemical, Biological and Physical Sciences. 7(1):115-121 
AlHafez, M, Kheder, F, Aljoubbeh, M. 2014. Polyphenols, flavonoids and (-)-epigallocatechin gallate in tea leaves and in their infusions under various conditions. Nutrition \& Food Science. 44(5):455-463

Alvarez-Suarez, J, M, González-Paramás, A, M, Santos-Buelga, C, Maurizio Battino. 2010. Antioxidant characterization of native monofloral cuban honeys. J. Agric. Food Chem. 58(17):9817-9824

Apriyantono, A, Fardiaz, D, Puspitasari, NLS, Budiyanto, S. 1989. Analisis Pangan: Petunjuk Laboratorium. IPB, Bogor

Ball, D, W. 2007. The chemical composition of honey. Journal of Chemical Education. 84(10):1643-1646

Bambang, K, Hastuti, P, Supartono, W. 1988. Pedoman Uji Inderawi Bahan Pangan. UGM, Yogyakarta

Bautista-Ortín, A, B, Martínez-Hernández, A, Ruiz-García, Y, Gil-Muñoz, R, GómezPlaza, E. 2016. Anthocyanins influence tannin-cell wall interactions. Food Chemistry. 206:239-248

Bogdanov, S. 2009. Honey. Bee Product Science, USA

Brigand, J, P, Nahon, P. 2016. Gastronomy and the citron tree (Citrus medica L.). International Journal of Gastronomy and Food Science. 3:12-16

BSN. 2013. Madu. Dilihat 17 November 2016. <http://sisni.bsn.go.id/index.php/ sni_main/sni/detail_sni/15777>

Chen, S, S, Liu, J, Y, Hsui, Y, R, Chang, S, T. 2006. Chemical polymorphism and antifungal activity of essential oils from leaves of different provenances of indigenous cinnamon (Cinnamomum osmophloeum). Biosource Technology. 97(2):306-312

Chumsri, P, Sirichote, A, Itharat, A. 2008. Studies on the optimum conditions for the extraction and concentration of roselle (Hibiscus sabdariffa Linn.) extract. Songklanakarin J. Sci. Technol. 30(Suppl.1):133-139

Codex Stan. 1981. Codex standard for honey. Dilihat 7 Oktober 2016. <http://www. aca.org.ro/content/media/pagini/ cxs_012e.pdf>

Cui, B, Hu, Z, Zhang, Y, Hu, J, Yin, W, Feng, Y, Xie, Q, Chen, G. 2016. Anthocyanins and flavonols are responsible for purple color of Lablab purpureus (L.) sweet pods. Plant Physiology and Biochemistry. 103:183-190
Da-Costa-Rocha, I, Bonnlaender, B, Sievers, H, Pischel, I, Heinrich, M. 2014. Hibiscus sabdariffa L. - a phytochemical and pharmacological review. Food Chemistry. 165:424-443

El Sohaimy, S, A, Masry, S, H, D, Shehata, M, G. 2015. Physicochemical characteristics of honey from different origins. Annals of Agricultural Sciences. 60(2):279-287

Farag, M, A, Rasheed, D, M, Kamal, I, M. 2015. Volatiles and primary metabolites profiling in two Hibiscus sabdariffa (roselle) cultivars via headspace SPME-GC-MS and chemometrics. Food Research International. 78:327-335

Farida, A, Ferawati, Arqomah, R. 2013. Ekstraksi zat warna dari kelopak bunga rosella (studi pengaruh konsentrasi asam asetat dan asam sitrat). Jurnal Teknik Kimia. 19(1):26-34

Fasoyiro, S, B. 2014. Physical, Chemical and Sensory Qualities of Roselle Water Extract-coagulated Tofu Compared with Tofu from Two Natural Coagulants. Nigerian Food Journal. 32(2):97-102

Farzaneh, V, Carvalho, I, S. 2015. A review of the health benefit potentials of herbal plant infusions and their mechanism of actions. Industrial Crops and Products. 65:247-258

Frewer, L, J, Bergmann, K, Brennan, M, Lion, R, Meertens, R, Rowe, G, Siegrist, M, Vereijken, C. 2011. Consumer response to novel agri-food technologies: Implications for predicting consumer acceptance of emerging food technologies. Trends in Food Science $\mathcal{E}$ Technology. 22(8):442-456

Gan, F, Chua, Y, S, Scarmagnani, S, Palaniappan, $\mathrm{P}$, Franks, $\mathrm{M}$, Poobalasingam, T, Bradshaw, T, D, Westwell, A, D, Hagen, T. 2009. Structure-activity analysis of 2'-modified cinnamaldehyde analogues as potential anticancer agents. Biochemical and Biophysical Research Communications. 387(4):741-747

General Ming's. 2013. History of korean citron tea. Dilihat 1 Desember 2016 <http://www.generalmings.com/ history-of-korean-citron-tea/>

Gheldof, N, Engeseth, N, J. 2002. Antioxidant capacity of honeys from various floral sources based on the determination of oxygen radical absorbance capacity and inhibition of in vitro lipoprotein 
oxidation in human serum samples. $J$. Agric. Food. Chem. 50(10):3050-3055

Gonzales-Palomares, S, Estarrón-Espinosa, M, Gómez-Leyva, J, F, AndradeGonzález, I. 2009. Effect of the temperature on the spray drying of roselle extracts (Hibiscus sabdariffa L.). Plant Foods. Hum. Nutr. 64(1):62-67

Guzman, J, D. 2014. Natural cinnamic acids, synthetic derivatives and hybrids with antimicrobial activity. Molecules. 19:19292-19349

Hashtjin, A, M, Abbasi, S. 2015. Nano-emulsification of orange peel essential oil using sonication and native gums. Food Hydrocolloids. 44:40-48

Hastuti, N, D. 2012. Pembuatan minuman fungsional dari madu dan ekstrak rosela (Hibiscus sabdariffa Linn.). Jurnal Teknologi Pangan. 3(1):29-63

Herrera-Arellano, A, Flores-Romero, S, hávez-Soto, M, A, Tortoriello, J. 2004. Effectivencess and tolerability of a standarized extracy from Hibiscus sabdariffa in patients with mild to moderate hypertention: a controlled and randomized clinical trial. Phytomedicine. 11(5):375-382

Imatome-Yun, N. 2012. Yuja Tea (Yuzu Citron Tea) Recipe. Dilihat 11 Oktober 2016. <http://koreanfood.about.com/ od/drinks/r/Yuja-Tea-Yuzu-CitronTea-Recipe.htm>

Jeney-Nagymate, E, Fodor, P. 2008. The stability of vitamin $C$ in different beverages. British Food Journal. 110(3):296-309

Karagül-Yüceer, Y, Coggins, P, C, Wilson, J, C, White, C, H. 1999. Carbonated yogurt-sensory properties and consumer acceptance. Journal of Dairy Science. 82(7):1394-1398

Kementerian Lingkungan Hidup dan Kehutanan. 2015. Statistik Kementerian Lingkungan Hidup dan Kehutanan Tahun 2014. Kementerian Lingkungan Hidup dan Kehutanan, Indonesia

Khatun, M, Eguchi, S, Yamaguchi, T, Takamura, H, Matoba, T. 2006. Effect of thermal treatment on radical-scavenging activity of some spices. Food Sci. Technol. Res. 12(3):175-185

Kimbal, JW. 1993. Biologi. Erlangga, Jakarta Kumalaningsih, S. 2006. Antioksidan Alami Penangkal Radikal Bebas, Sumber, Manfaat, Cara Penyediaan dan Pengolahan. Trubus Agrisarana, Surabaya
Kurowska, E, M, Manthey, J, A. 2004. Hypolipidemic effects and absorption of citrus polymethoxylated Flavones in hamsters with diet-induced hypercholesterolemia. J. Agric. Food. Chem. 19:2879-2886

Lee, K, G, Shibatomo, T. 2002. Determination of antioxidant potential of volatile extracts isolated from various herb and spices. J. Agric. Food. Chem. 50(17):49474952

Ma, X, Liu, Y, Li, X, Xu, J, Gu, G, Xia, C. 2015. Water: the most effective solvent for liquid-phase hydrodechlorination of chlorophenols over raney ni catalyst. Applied Catalysis B: Environmental. 165:351-369

Mahardika, B, D. 2014. Uji Penurunan Tingkat Keasaman dan Parameter Kimia pada Minuman Sari Rosela (Hibiscuss sabdariffa) Berkarbonasi. Skripsi. UB. Malang

Mardiah, SH, Arifah, R, Reki, W. 2009. Budi Daya dan Pengolahan Rosela Si Merah Segudang Manfaat. Agromedia Pustaka, Jakarta

Mentari, F, D, P, Susanto, W, H. 2014. Pengaruh proporsi (buah:sukrosa) dan lama osmosis terhadap kualitas sari buah stroberi (Fragaria vesca L.). Jurnal Pangan dan Agroindustri. 2(2): 82-90

Molyneux, P. 2004. The use of stable free Radical diphenylpicrylhydrazyl (DPPH) for estimating antioksidan activity. Songklanakarin J. Sci. Technol. 26(2):211219

Moss, BW. 2002. The Chemistry of Food Colour. CRC Press, Washington

Muhilal dan Komari. 2000. Ester-C Vitamin C Generasi III. PT Gramedia Pustaka. Jakarta

Nidya, S. 2009. Pengaruh Jumlah Ekstrak Kelopak Bunga Rosela terhadap Sifat Fisikokimia dan Organoleptik Marshmallow. Skripsi. Universitas Katolik Widya Mandala. Surabaya

Nopwinyuwong, A, Trevanich, S, Suppakul, P. 2010. Development of a novel colorimetric indicator label for monitoring freshness of intermediate moisture dessert spoilage. Talanta. 81(3):11261132

Novandra, A, Widnyana, M. 2013. Peluang pasar produk perlebahan indonesia. Dilihat 10 Juni 2016. <http://www. forda-mof.org/files/PELUANG_ 
PASAR_PRODUK_PERLEBAHAN INDONESIA.pdf>

Padayachee, A, Netzel, G, Netzel, M, Day, L, Zabaras, D, Mikkelsen, D, Gidley, M, J. 2012. Binding of polyphenols to plant cell wall analogues - part 1: anthocyanins. Food Chemistry. 134(1):155-161

Peter, KV. 2001. Handbook of Herbs and Spices Volume I. Woodhead Publishing, India

Pohorille, A. 2005. Is Water a Universal Solvent for Life?. Proceeding Open Questions on the Origins of Life, Leicester, UK, pp. 1-2

Radice, M, Manfredini, S, Ziosi, P, Dissette, V, Buso, P, Fallacara, A, Vertuani, S. 2016. Herbal extracts, lichens and biomolecules as natural photo-protection alternatives to synthetic UV filters a systematic review. Fitoterapia. 114:144162

Rahayu, WP. 2001. Penuntun Praktikum Penilaian Organoleptik. IPB. Bogor

Ramírez-Rodrigues, M, M, Balaban, M, O, Marshall, M, R, Rouseff, R, L. 2011. Hot and cold water infusion aroma profiles of hibiscus sabdariffa: fresh compared with dried. J. Food Sci. 76(2):C212-217

Ranken, MD, Kill RC. 1997. Food Industries Manual. Chapman and Hall, UK

Richana, N. 2009. Ubi Kayu dan Ubi Jalar. Nuansa Cendekia, Bogor

Rieder, A, Ballance, S, Knutsen, S, H. 2015. Viscosity based quantification of endogenous $\beta$-glucanase activity in flour. Carbohydrate Polymers. 115:104-111

Rigaux, C, Georgé, S, Albert, I, Renard, C, M, G, C, Carlin, F. 2016. A mechanistic and probabilistic model estimating micronutrient losses in industrial food processing: vitamin $\mathrm{C}$ and canned green beans, a case-study. LWT - Food Science and Technology. 69:236-243

Ruark, A, Vingerhoeds, M, H, Kremer, S, Nijenhuis-de Vries, M, A, Friszman, B, P. 2016. Insights on older adults' perception of at-home sensory-hedonic methods: a case of ideal profile method and CATA with ideal. Food Quality and Preference. 53:29-38

Šebjan, U, Tominc, P. 2016. Young customers' organoleptic assessment of tomatoes with different geographic origins: a preliminary study. British Food Journal. 118(4):871-884

Shoosh, W, G, A. 1997. Chemical Composition of Some Roselle (Hibiscus sabdar- iffa) Genotypes. Tesis. University of Khartoum. Sudan

Sihombing, DTH. 2005. Ilmu Ternak Lebah Madu. UGM Press, Yogyakarta

Sudarmadji, SB, Haryono, Suhardi. 1997. Prosedur Analisa untuk Bahan Makanan dan Pertanian. PT. Liberty, Yogyakarta

Suhesti, E, Hadinoto. 2015. Hasil hutan bukan kayu Madu sialang di kabupaten kampar (studi kasus: kecamatan kampar kiri tengah). Wahana Forestra: Jurnal Kehutanan. 10(2):16-26

Tau, T, Gunasekaran, S. 2016. Thermorheological evaluation of gelation of gelatin with sugar substitutes. LWT-Food Science and Technology. 69:570-578

Theron, K, A, Muller, M, Van der Rijst, M, Cronje, J, C, le Roux, M, Joubert, E. 2014. Sensory profiling of honeybush tea (Cyclopia species) and the development of a honeybush sensory wheel. Food Research International. 66:12-22

Tsai, P, J, Mclntosh, J, Pearce, P, Camden, B, Jordan, B, R. 2002. Anthocyanin and Antioxidant capacity in roselle (Hibiscus sabdariffa L.) extract. Food Research International. 35(4) : 351-356

Uckiah, A, Goburdhun, D, Ruggoo, A. 2009. Vitamin $C$ content during processing and storage of pineapple. Nutrition $\mathcal{E}$ Food Science. 39(4):398-412

USDA. 2016. Basic report 19296, honey. Dilihat 9 Juni 2016. <https://ndb.nal. usda.gov/ndb/foods/show/6287>

Utama-ang, N, Chompreeda, P, Haruthaithanasan, $\mathrm{V}$, Lerdvuthisopon, $\mathrm{N}$, Suwonsichon, T, Watkins, B, A. 2007. Optimization of chemical properties, sensory descriptive, and consumer acceptance of jiaogulan tea using response surface methodology (RSM). CMU. J. Nat. Sci. 6(1):101-119

Verzera, A, Tripodi, G, Condurso, C, Dima, G, Marra, A. 2014. Chiral volatile compounds for the determination of orange honey authenticity. Food Control. 39:237-243

Winarno, FG. 2008. Kimia Pangan dan Gizi. Gramedia Pustaka Utama, Jakarta

Yulia, A, Rahmi, S, L, Madyawati, L. 2013. Minuman fungsional ekstrak kulit kayu manis dan kelopak bunga rosela. Jurnal Penelitian Universitas Jambi: Seri Sains. 15(1):79-84

Yulia, A, Suparmo, Harmayani, E. 2011. Studi pembuatan minuman ringan berk- 
Jurnal Teknologi Pertanian Vol. 18 No. 1 [April 2017] 21-32

Inovasi Produk Citrus Infused Honey Tea dengan Penambahan Rosela [Murtini dkk.]

abonasi dari ekstrak kulit kayu manis-madu. Jurnal Penelitian Universitas Jambi: Seri Sains. 13(2): 1-4

Yuwono, SS, Susanto, T. 1998. Pengujian Sifat Pangan. UB, Malang
Zeleny, M. 1982. Multiple Criteria Decision Making. McGraw-Hill, New York

Zhang, Q, Ruan, J. 2016. Tea: analysis and tasting. Encyclopedia of Food and Health. $256-267$ 